\title{
Forgetful Audiences in Julius Caesar
}

\section{Claire Guéron}

\section{(2) OpenEdition \\ Journals}

Electronic version

URL: http://journals.openedition.org/shakespeare/1959

DOI: 10.4000/shakespeare.1959

ISSN: 2271-6424

\section{Publisher}

Société Française Shakespeare

\section{Printed version}

Date of publication: 1 April 2013

Number of pages: 197-208

ISBN: 2-9521475-9-0

\section{Electronic reference}

Claire Guéron, «Forgetful Audiences in Julius Caesar », Actes des congrès de la Société française Shakespeare [Online], 30 | 2013, Online since 03 April 2013, connection on 19 April 2019. URL : http:// journals.openedition.org/shakespeare/1959; DOI : 10.4000/shakespeare.1959 


\section{Shakespeare et la mémoire}

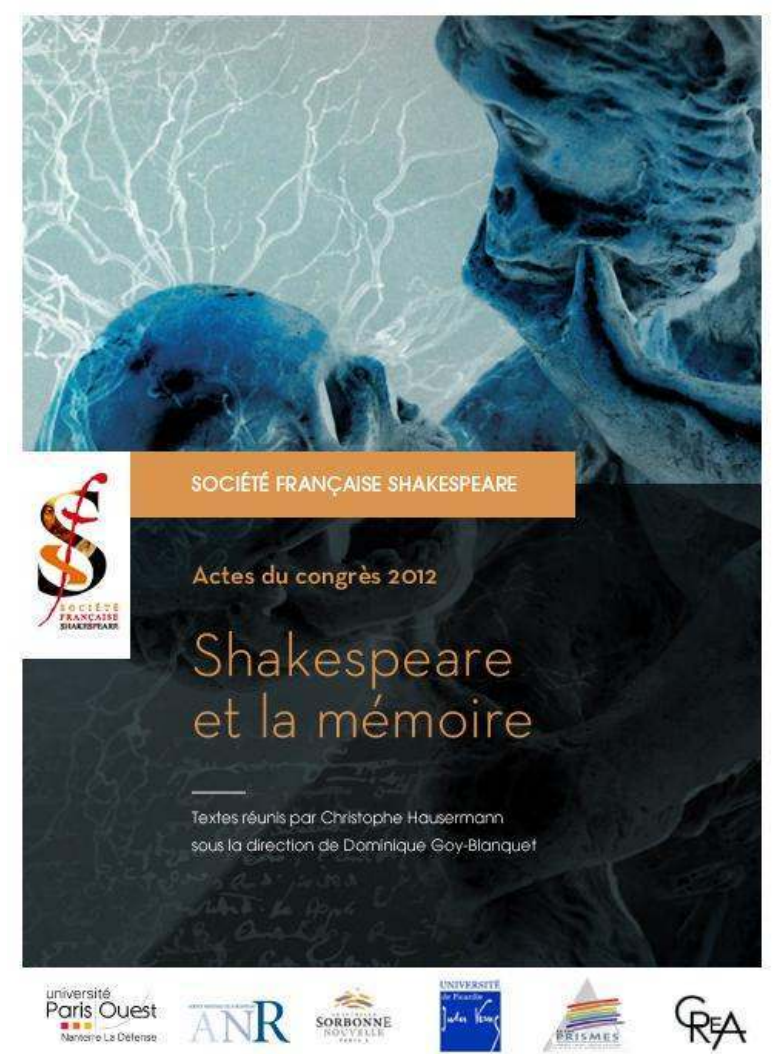

actes du Congrès

organisé par la

SOCIÉTÉ FRANÇAISE SHAKESPEARE

les 22, 23 et 24 mars 2012

textes réunis par

Christophe HAUSERMANN

sous la direction de

Dominique GoY-BLANQUET 


\section{COUVERTURE}

d'après l'affiche de Claire Colombet

conception graphique et logo

Pierre Kapitaniak

mise en page et corrections

Christophe Hausermann

(C) 2012 Société Française Shakespeare

Institut du Monde Anglophone

Université de Paris III - Sorbonne Nouvelle

5 rue de l'École de Médecine 75006 Paris

www.societefrancaiseshakespeare.org

Tous droits de traduction, de reproduction et d'adaptation réservés pour tous les pays 
Forgetful Audinces in Julius Caesar

Claire Guéron

On note dans Jules César une récurrence d'épisodes où la mémoire du spectateur défaille, quand des personnages oublient une scène à laquelle ils viennent d'assister ou la retiennent de façon approximative. Cet article s'intéresse aux manifestations dramatiques et méta-théâtrales de ce phénomène, et avance que ces scènes d'oubli sont pour l'auteur le moyen de démontrer le caractère fuyant de la mémoire empirique et de proposer que le théâtre, plutôt que la salle de classe, constitue un terrain propice à l'exercice de cette mémoire.

Julius Caesar exhibits a pattern of audience forgetfulness, when characters forget scenes they have just witnessed, or when they remember them imperfectly. This paper explores the dramatic and meta-dramatic manifestations of this phenomenon, and argues that scenes of audience forgetfulness allow the playwright both to foreground the elusiveness of empirical memory and to promote the playhouse, in opposition to the schoolroom, as a training-ground for memory.

$\mathrm{I}$

$\mathrm{n}$ the second scene of Julius Caesar, Brutus asks Casca to describe Caesar's behaviour at the feast of the Lupercals. When Casca replies by asking him if he was there, Brutus tartly replies that had he been there, he would have no need to ask. ${ }^{1}$ This assumption of perfect witness recall is in keeping with Brutus' cut-and-dried world view, and yet it is consistently belied throughout the play, as characters repeatedly forget what they have just witnessed (visually and aurally). Out of such patterns, which are subtly extended to the meta-dramatic level, the figure of the forgetful audience emerges. According to me, this figure constitutes a critique of the confident models of human memory found in the works of classical and humanist writers, and a means of exploring the role of the playhouse in the consolidation of the empirical memory. I will start out by showing that the forgetful audience is at the heart of Julius Caesar's dramatic strategy. I will then argue that audience forgetfulness functions as a trope for the elusive nature of experience, one that defies capture by the traditional arts of memory. Finally, I will turn to the remedies to faulty memory that the play does seem to offer.

I. Forgetful audiences as rhetorical strategy

\footnotetext{
${ }^{1}$ BRutus. Ay, Casca. Tell us what hath chanced today, That Caesar looks so sad.

CASCA. Why, you were with him, were you not?

BRUTUS. I should not then ask Casca what had chanced. (I.ii.218-221).

All references are to William Shakespeare: The Complete Works, eds. Stanley Wells and Gary Taylor, Oxford, Clarendon Press, 1986.
} 
In Julius Caesar, spectatorship is marred by forgetfulness. Plebeians, in particular, seem to lack retentive powers. In the first scene, a group of carousing commoners are berated for forgetting Pompey's triumphant progresses through Rome. Later in the play, Mark Antony upbraids his plebeian audience for forgetting the will he mentioned only minutes before. Yet, audience forgetfulness is not restricted to the common people. Casca, too, it seems, has trouble recalling and reporting the scene he witnessed at the Lupercals. Much to Brutus' disgust, he leaves out important details, jumbles chronology, requires constant prompting, and admits - somewhat archly - that he is unable to remember some of what took place: "there was more foolery yet, if I could remember it" (I.ii.286-7).

There is a meta-dramatic dimension to all these episodes. The scenes characters remember imperfectly are all ritualized and spectacular: the events at the Lupercals involve a highly dramatized proffering of the crown by Antony, and an equally dramatic refusal of that crown by Caesar. Pompey's entrance into Rome is described in terms that recall Tudor pageantry, and Antony's funeral oration is extremely theatrical, with its well-timed pauses, physical posturing and use of an array of props that includes a dead body. Antony's speech, however, differs from the previous examples in that audience forgetfulness is part of a rhetorical and dramatic strategy. Though Antony feigns chagrin at his audience's forgetting the will, it is clear that he has himself orchestrated that forgetfulness by introducing the distraction of Caesar's body. By reactivating a theme he has already introduced, Antony gives it greater resonance and works the people up to the frenzy he has been aiming for.

It is probably no accident that Antony is identified as an avid playgoer from the very beginning. Caesar's reference to Antony's taste for plays ${ }^{2}$ brings out the meta-dramatic dimension of the Roman hero's manipulation of the crowd. Antony's manipulation of audience memory may be perceived as a mise en abyme of Shakespeare's own, in so far as the play's poetics rely on a pattern of reactivating dormant memories. In Shakespeare: Seven Tragedies Revisited, E. A. Honigman shows that the audience's attitude towards Brutus is shaped

\footnotetext{
2 "He loves no plays, / As thou dost, Antony" (I.ii.204-205).
} 
by such a pattern of reactivation. ${ }^{3}$ Reactivation of previous incidents is of course at the heart of such devices as foreshadowing and dramatic irony, and, one might argue, certainly not the exclusive province of Julius Caesar, or even Shakespeare. However, Julius Caesar is remarkable in that reactivation does not lead to hermeneutic closure, but to increased forgetfulness and confusion. The poetics of Julius Caesar involves a pattern of inviting the audience to think back to previous moments of the play, while muddying the waters, so that confusion results. Such a strategy is at work when Brutus tells the conspirators to "remember/ What [they] have said" (II.i.221-222) right after they decide not to swear an oath, thus leaving the audience with a vague impression that an oath has indeed been sworn. It is also at work when Brutus reminds Cassius that Caesar was killed for supporting robbers, though in fact no such reason was adduced earlier in the play, or when Cassius, having learned of Portia's death, wonders how Brutus was able to forbear from killing him during their quarrel. "How 'scaped I killing when I crossed you so?" (IV.ii.204). In all of these instances, the attention of the offstage audience is directed back to past events it has witnessed, and encouraged to reassess them in the light of new input. Terence Hawkes identifies such a pattern in Hamlet, in which he claims the audience is systematically bullied into reassessing Hamlet's behavior in a favorable light:

Throughout, it seems to me, the audience of Hamlet might legitimately feel that it is being buttonholed, cajoled, persuaded by participants in the play to look back, to 'revise', to see things again in particular ways, to 'read' or interpret them along specific lines to the exclusion of others. $^{4}$

In Julius Caesar, I would argue, no such hermeneutic agenda is perceptible. Instead, the play encourages the audience to look back while setting it up for a failure of recall. This can be demonstrated in the quarrel scene, which I will now turn to.

Contemporary viewers apparently considered the scene of the quarrel between Brutus and Cassius one of the play's most memorable ones. In his diachronic study of Julius Caesar on stage, John Ripley

\footnotetext{
3 E. A. Honigmann, Shakespeare: Seven Tragedies Revisited, The Dramatist's Manipulation of Response, Basingstoke, Palgrave, 2002.

4 Terence Hawkes, That Shakespeherian Rag, Essays on a Critical Process, London and New York, Methuen, 1986, p. 98.
} 
noted "the emergence of the quarrel scene as one of the play's most admired features" 5 and quoted Leonard Digges's lines of verse describing the scene's impact on the audience:

So have I seen, when Caesar would appeare,

And on the stage at half-sword parley were

Brutus and Cassius: oh how the Audience,

Were ravish'd, with what wonder they went thence...6

The scene's sticking power is somewhat ironic given how much forgetting takes place in it. At one point, Cassius responds to Brutus' reproaches by saying:

[...] I am a soldier, I,

Older in practice, abler than yourself

To make conditions

(IV.ii.84-86).

Later in the scene, Brutus refers back to Cassius' words: "You say you are a better soldier. Let it appear so" (IV.ii.107-108), to which Cassius replies:

You wrong me every way, you wrong me, Brutus, I said an elder soldier, not a better.

Did I say better?

(IV.ii.111-113)

The question "Did I say better?" is addressed to Cassius himself as much as to Brutus. By metalepsis, it could also be taken as an address to the audience, which is in the same position to answer it as the characters. If the question is allowed to hang in the air for a few seconds, the audience's mind will naturally - if fleetingly - turn back to the earlier moment in the quarrel alluded to, in an effort to replay the conversation. Probably, the memory will already be too hazy for recall. According to a 1959 study by L. R. and M. J. Peterson, data is stored in the brain's short-term memory (or working memory) for about eighteen seconds before it is forgotten. ${ }^{7}$ In this case, about ninety seconds of dramatic and real time have elapsed. The spectator is not at leisure to think back for too long, because of the ongoing action's claim

5 John Ripley, Julius Caesar on Stage in England and America, 1599-1973, Cambridge, C.U.P., 1980, p. 15.

${ }^{6}$ Leonard Digges, Poems: Written by Wil. Shakes-speare Gent.,1640, quoted in Ripley, op. cit., p. 15 .

7 R. Lloyd and Margaret Jean Peterson, "Short-Term Retention of Individual Verbal Items", Journal of Experimental Psychology, 58.3, September 1959, p. 193-8, p. 195. 
on his or her attention. From our vantage point as readers, however, we may now turn back a page or two and look up what was actually said, assuming the actor stuck to his part as it appears in the 1623 Folio, the sole authoritative text. With the text in hand, we can easily verify that Cassius did not say better but "abler". Does it matter? Semantically, yes. "Abler" is synonymous with "better", but the infinitive clause modifies the semantics, since "abler to make conditions" means a better negotiator, whereas "a better soldier" means a better fighter. Even if the audience's memory of these words has not faded within the prescribed eighteen seconds, it is probable that the characters' subsequent attempt to recover the truth will have muddied the waters so thoroughly as to make the memory completely irretrievable. This technique of obliteration through synonymy is close to that described by Umberto Eco in his "An Ars Oblivionalis, forget it!" In a playful exploration of strategies for inducing oblivion, Eco writes:

It is possible [...] to use a mnemotechnics (and, in general, a semiotics) to confuse memories, even if not to forget. Let us consider several mechanisms in which a notion or expression is not forgotten but comes to be confused with other notions or other expressions. The confusion can arise both between expressions (confusion caused by pseudosynonymy, as when I confuse the words paronomasia and antonomasia) and between an expression and two signifieds, notions, or definitional contents (as, for example, when one does not remember whether fraise means "blackberry" or "blueberry"). ${ }^{8}$ Neither of these phenomena ever appears by subtraction (there was something that then disappeared); rather, they appear by addition (two notions or terms are superimposed in memory, and one can no longer tell which is right). ${ }^{9}$

This strategy of audience confusion (which I will continue to speak of as a form of forgetfulness in spite of Eco's demur) is part of the play's poetics. Generally, such patterns of pointing back and erasing create a longing for a lost past, and contribute to the overriding mood of regret at the end of the play. Another effect is that by thrusting the audience into the same cognitive space as the characters, such episodes of confusion about the past promote identification and

\footnotetext{
8 The original Italian reads "non saprò mai se strawberry vuole dire 'mora' o 'mirtillo", suggesting that the two wrong translations for "fraise" are Eco's little joke rather than an error in translation.

${ }^{9}$ Umberto Eco, “An Ars Oblivionalis, forget it!”, tr. Marilyn Migiel, PMLA, vol. 103.3, May, 1988, p. 254-261, p. 259.
} 
sympathy. In particular, sympathy for Cassius is generated in the quarrel scene, where his many memory lapses appear less contrived than if we had not partaken of some of them. Reaching further back, audience forgetfulness may resonate with Caesar's epileptic fit, and his resulting amnesia. The sense of a shared consciousness emerges, with the frailties of human memory binding characters and audience in a common state of uncertainty.

Audience forgetfulness, then, can be either harnessed or induced as part of the play's rhetoric. The basic psychology behind some of these rhetorical tricks was well known in Shakespeare's day. Reactivation of buried memories, for example, apart from forming the basis of Plato's metaphysics of reminiscence, was discussed by Quintilian from a psychological perspective. In his Institutes, Quintilian advised his reader to focus on the troublesome parts when memorizing a text:

Thus, only the passages which tend to slip from the memory are repeated with a view to fixing them in the mind by frequent rehearsal although as a rule the mere fact that they once slipped our memory makes us ultimately remember them with special accuracy. ${ }^{10}$

A major difference with the episodes we have been looking at, however, is that Quintilian, here, is concerned with the orator's memory, rather than the listener's. This is characteristic of classical and early humanist treatises on rhetoric, which defined the ability to memorize a text as the fourth essential skill of an orator, until Peter Ramus's influential works changed and reorganized these skills the middle of the $16^{\text {th }}$ century. This implied a model of memory largely based on memorization. By shifting the emphasis to the audience's memory, Shakespeare offers a more empirical model of memory as the capturing of a flow of perceptions.

${ }^{10}$ Quintilian, The Institutio Oratoria, tr. H. E. Butler, Loeb Classical Library, Cambridge, Ma. and London, Harvard University Press, 1993 (first published 1922), Book XI, p. 233. 


\section{Experience and the arts of memory}

"The theatre", Peter Holland writes, is "the place where the mind investigates how it remembers". ${ }^{11}$ Dennis Kennedy explains why this is so: "Performance is one of memory's greatest tests, precisely because performance does not elude time, because it decays before our eyes, and thus in the moment of its accomplishment escapes into memory." 12

Holland's and Kennedy's statements about the theatre being the place where memory is tested and investigated imply a phenomenological proximity between spectatorship and experience. Being a spectator can be considered as an experience which consists in a sequence of sense impressions. In Julius Caesar, the proximity is also driven home by the characters' equation of wisdom with visual impressions accumulated over time. "I have seen more days than you" (IV.i.18), Antony says to Octavius in an attempt to clinch an argument. This will become "I have seen more years, I'm sure, than ye" (IV.ii.186) in the poet's mouth, a line Shakespeare found almost verbatim in Plutarch.

Forgetful audiences allow Shakespeare to demonstrate the frailty of empirical memory, as opposed to the robust process of recollection described in Cicero, Quintilian and their $\mathrm{XVI}^{{ }^{\text {th}}}$-century followers, including Sir Thomas Elyot and Thomas Wilson in England. The opposition is further emphasized by the play's many references to the classical arts of memory, and to the humanist schoolroom.

In the second scene of the play, after Brutus painstakingly asks Casca about the Lupercal episode, he expresses surprise at his friend's dullness, contrasting it with his brightness at school "What a blunt fellow is this grown to be! / He was quick mettle when he went to school (I.ii.295-296)". To an educated Englishman in the audience, "school" would have suggested an English grammar school, a place where boys memorized passages from Virgil and rules from Lily's grammar. In grammar school, boys also studied Cicero's De Oratore, with its explanation of how to memorize a speech by organizing it into places of

${ }^{11}$ Peter Holland, "On the Gravy Train: Shakespeare, Memory and Forgetting" in Shakespeare, Memory and Performance, ed. Peter Holland, Cambridge, C.U.P., 2007, p. 207-36, p. 231.

12 Dennis Kennedy, "Memory, performance, and the Idea of the Museum" in Holland, op. cit., p. 329. 
memory. Jeffrey Dolven has remarked on the way Elizabethan schoolroom exercises tended to abolish the diachronic extension of what is remembered, by organizing knowledge spatially rather than temporally, and by compressing empirical time into eternal truths. Invoking what he calls "the anti-narrative bias of humanism", Dolven writes that "[...] the classroom's exercises [were] constructed to impose atemporal conceptions on time-bound materials". ${ }^{13}$ A bright student, it seems, would be no better equipped than a dull one to capture the evanescent flow of experience and redeliver it in coherent narrative form. The limits of the classical arts of memory are more obviously illustrated in the scene between Brutus and his wife Portia, when Portia reminds Brutus of his churlish response to her requests for information on the previous night:

$$
\begin{aligned}
& \text { yesternight at supper } \\
& \text { You suddenly arose, and walked about } \\
& \text { Musing and sighing, with your arms across; } \\
& \text { And when I asked you what the matter was, } \\
& \text { You stared upon me with ungentle looks. } \\
& \text { I urged you further; then you scratched your head, } \\
& \text { And too impatiently stamped with your foot. } \\
& \text { Yet I insisted; yet you answered not, } \\
& \text { But with an angry wafture of your hand } \\
& \text { Gave sign for me to leave you (II.i.237-246; my emphasis) }
\end{aligned}
$$

Here, Portia seems to be following the classical principle of memory places, in particular those described by Thomas Wilson. In his 1560 Arte of Rhetoricke, Wilson explained that the human body could be used to provide loci, or "places of memory", conceptual boxes in which parts of a speech could be mentally stored and then retrieved for delivery. He did not follow Peter of Ravenna in using the bodies of beautiful women as memory places, but concentrated on the head of the interlocutor: "Some againe will set their places in his head or bodie, with whom they speake. As to make the nose, the eyes, the forhead, the haire, the eares, and other partes to serue for places." 14

On the face of it, Portia's speech seems to illustrate the usefulness of the classical memory arts for capturing a scene unfolding

13 Jeffrey Dolven, Scenes of Instruction in Renaissance Romance, Chicago and London, The University of Chicago Press, 2007, p. 56.

14 Thomas Wilson, The Arte of Rhetoricke (1560), e-text, Renascence Editions, 1998, (transcribed by Judy Boss, Omaha, NE, University of Oregon, from Wilson's Arte of Rhetorique 156o. Ed. G. H. Mair. Oxford, Clarendon Press, 1909), book 3, p. 42. 
in time. However, the odd little pantomime she describes strikes the audience as bizarre and artificial, underscoring instead how unlikely it would be for experience to present itself in such ready-made units. A more conventional use of the places of memory appears in the third scene, when Cassius instructs Cinna to place notes in Brutus' path as part of the plan to win him over to the conspiracy:

Good Cinna, take this paper,

And look you lay it in the praetor's chair,

Where Brutus may but find it; and throw this

In at his window. Set this up with wax

Upon old Brutus' statue. All this done,

Repair to Pompey's Porch, where you shall find us

(I.iii.142-147; my emphasis).

In Plutarch, the notes were all left in one place, "the Praetor's seat". Shakespeare's paper chase is modelled on the classical memory method of architectural loci as outlined in Cicero's De Oratore, the pseudo-Ciceronian Ad Herennium, and Quintilian's Institutes, which involved a mental walk through buildings whose inner spaces, individualized by striking images, contained the parts of the speech to be memorized. Not only did the walk allow the speaker to recollect the text in its entirety, but from the Renaissance on, as Frances Yates explains in The Art of Memory, the images also signified in their own right, and constituted a symbolic representation of cosmological and metaphysical systems. Peter of Ravenna, for example, and Cosmus Rosselius after him, used churches and abbeys for their loci. In the passage quoted above, Cassius is setting up a memory walk for Brutus, which will allow him to memorize Cassius' written calls to action, and to associate himself with Rome's heroes by touring the city's commemorative monuments. This memory walk puts Brutus in the position of an orator, rather than a spectator. Though such a position may appear to be a strong one, it bars him from using the materials of first-hand experience. Here, as in the humanist classroom, the arts of memory are associated with the voices of authority, as opposed to those of experience.

The fallibility of memory as a recorder of experience raises the question of how knowledge derived from experience can be balanced against knowledge derived from authority, a question that was being hotly debated by pedagogues and scholars in Shakespeare's day. Whereas Roger Ascham, in his Schoolmaster (1570), had called 
experience "the common schoolhouse of fools and ill men", 15 other voices, John Lyly's among them, claimed a formative role for experience. Shakespeare, however, is less concerned with the relative virtues of learning and experience, than with the possibility of making experience stick, so that it may be put to pragmatic use. The question cuts to the heart of the play, as Brutus' decision to kill Caesar involves the weighing of remembered experience against the remembered voice of authority. On the side of experience is Brutus' memory of a consistently reasonable Caesar: "I have not known when his affections swayed / More than his reason (II.i.20-21)". On the side of authority is the commonplace that powerful men turn into tyrants. The balance is skewed in favour of authority, for Brutus' memory of Caesar is not powerful enough to be arranged in a strong narrative arc, one that might have allowed him to extrapolate Caesar's future behaviour from his past. Authority, on the other hand, comes in the vivid form of mnemonic images, with a profusion of snakes, suns, clouds, ladders, and emblematic imagery, all organized into a ready-made plot. It is no surprise, then, that authority (and murder) should win the day.

By holding up the weak staying power of witnessed scenes against the vivid paraphernalia of received knowledge, Shakespeare suggests that the humanist approach to memory, with its emphasis on memorizing authoritative texts, may lead to unbalanced choices, and adversely affect the course of history. However, though classical mnemonics are shown to be inadequate to rein in the elusiveness of experience, the play suggests that such methods do exist. While presenting the audience's memory as defective, Shakespeare uses the stage as a model of how to counter the natural weakness of retention.

\section{Remedies for forgetfulness}

As Laurie Maguire, Peter Holland and Andrew Gurr have shown, Shakespeare's audiences displayed a range of behaviours aimed at retaining as much as they could of the plays they witnessed. Notetaking proliferated, learned men quoted lines from plays they had attended in their letters, and spectators such as Simon Forman and John Manningham hurried home after performances to consign to

15 Roger Ascham, The Schoolmaster (1570), ed. Lawrence V. Ryan, Ithaca, New York, Cornell University Press, 1967, p. 51, quoted in Dolven, p. 68. 
paper their still fresh memories in diaries and commonplace books. Some of this note-taking may have been of a professional sort, as the so-called "bad" quartos are believed to have been pirate editions based on memorial reconstructions and shorthand notes. ${ }^{16}$ Still, much of this recording was of a private order, and may have derived from anxieties about the playgoer's powers of retention. Peter Holland notes a sense of urgency in Simon Forman's post-performance reconstruction of a play:

[...] Simon Forman [...] in his 'Bocke of Plays' in 1611, writes as it were to and for himself $[\ldots]$ repeatedly the aggressive command 'Remember', five times in his account of the non-Shakespearean play about Richard II alone. The report becomes a series of instructions to himself to 'Remember therein how ... Also remember how .... Remember also ... Remember therin Also howe ... Remember also howe ...' an aggregation of memories through the conscious act of remembering in the writing of the performance into memory. ${ }^{17}$

This urgency suggests that memory itself, rather than the content of memory, is at stake.

In Julius Caesar, Shakespeare gives us meta-dramatic representations of these recording practices. In Cassius and Brutus' quarrel over "better" and "elder", for example, we have an image of two playgoers attempting to reconstruct a scene by comparing mental notes. Casca's bumbling narration of the celebration of the Lupercal may be regarded as an image of a playgoer telling a friend about a play he has seen, thus allowing the memory to take shape in the telling. In Cassius' evocation of Caesar instructing his troops to "write his speeches in their books" (I.ii.26), there may be a dramatization of the short-hand note-taking that took place during performances at the Inns of Court and in the public playhouse. When, after the quarrel scene, Brutus leafs through the pages of the book he has nearly lost, the image is that of a playgoer going over his shorthand notes to check a line. This meta-dramatic interpretation is reinforced by the words Brutus speaks as he looks for his place in his book, the same words

\footnotetext{
${ }^{16}$ For a discussion on this theory, see Laurie E. Maguire, Shakespearean Suspect Texts, The 'Bad' Quartos and their Contexts, Cambridge, C.U.P., 1996, especially p. 3-20 and 325338.

17 Peter Holland, op. cit. p. 211. For unabridged quotations from Forman's "Bocke of Plays", see The Riverside Shakespeare, eds. G Blackmore Evans and J.J.M. Tobin, $2^{\text {nd }}$ ed., Boston, Houghton Mifflin Company, 1997, p. 1966-8.
} 
Hamlet will use when recalling a speech in a play he has witnessed: "Let me see, let me see" (IV.ii.326 and II.ii.450-451).

Playgoing mimics experience, but it occurs in a more controlled environment, so that the theatre can be used as a training-ground for memory. The playhouse then becomes invested with the epistemological and cognitive mission of the schoolroom, allowing the audience to both explore and exercize its memory.

\section{Conclusion}

Through his forgetful audiences, Shakespeare explores both his craft and the cognitive processes which its success relies on. This allows him to posit a pedagogical role for the playhouse. At a time of increasing puritan attacks against the theatre, accused of being the place where audience members "forgot themselves", ${ }^{18}$ Shakespeare suggests that the playhouse, rather than the schoolroom, is where the mind learns how to remember. Learning to remember, however, can mean learning to outsource memory through note-taking, a process that was to become the cornerstone of Francis Bacon's program of empirical education. In its emphasis on empirical memory, the play points forward to the paradigm shift of the mid to late XVII ${ }^{\text {th }}$ century, when experience rather than authority became the subject matter of memory, and chronology rather than topography its organizational principle. ${ }^{19}$ At the most immediate level, however, Julius Caesar also gives us an oddly intimate view of history, by reducing the scale of historical time to that of a thought fading from memory.

Claire Guéron

Université de Bourgogne (Dijon)

\footnotetext{
18 See for instance William Rankins, A mirrour of monsters (1587), from Henry E. Huntington Library and Art Gallery, EEBO, http://eebo.chadwyck.com/home, last viewed June $1^{\text {st }} 2012$.

${ }^{19}$ See Donald Beecher, "Recollection, Cognition and Culture: An Overview of Renaissance Memory" in Ars Reminiscendi Mind and Memory in Renaissance Culture, eds. Donald Beecher and Grant Williams, Toronto: Center for Reformation and Renaissance Studies, 2009, p. 415.
} 